\title{
THE ECONOMIC AND SPATIAL RESTRUCTURING AND DEVELOPMENT PROCESS IN THE NORTH SECTOR OF THE METROPOLITAN REGION OF BELO HORIZONTE, Minas GERAIS
}

\author{
REESTRUTURAÇÃO ECONÔMICO-ESPACIAL \\ E DESENVOLVIMENTO NO VETOR NORTE \\ DA REGIÃo METROPOLITANA DE BELO HORIZONTE, \\ MINAS GERAIS
}

\author{
Luciano dos Santos Diniz A, B, C, D, E, F \\ Centro Federal de Educação Tecnológica de Minas Gerais, Departamento de Ciências Sociais Aplicadas, \\ Belo Horizonte, MG, Brazil \\ Maura Pardini Bicudo Véras A, B, C, D, E, F \\ Pontifícia Universidade Católica de São Paulo, Departamento de Sociologia, São Paulo, SP, Brazil
}

\begin{abstract}
A B S T R A C T : This aim of this study is to evaluate the economic and spatial restructuring process implemented by the public authorities in the North Sector of the Metropolitan Region of Belo Horizonte, and the appropriation of space by the land and real estate markets in the north and periphery of the capital, seeking to identify the elements that have contributed to altering the land order and to the elitization of spaces. The metropolitan strategic plan sought to diversify the industrial base of the region by attracting investments and creating high-tech hubs. In order to ensure its greater competitiveness on the global stage, it was accompanied by large public infrastructure works and support services. The present study has concluded that the modifying actions undertaken by the public authorities have influenced the valorization of urban land, the appropriation of the space by the land/real estate markets and the elitization of the north and peripheral region of the capital, thus supporting the thesis of the city as an urban growth machine.
\end{abstract}

K E Y W O R D S : city; metropolitan region; strategic planning; economic and spatial restructuring; development.

R E S U M O : O trabalho tem como objetivo avaliar o processo de restruturaçáo econômico-espacial implementado pelo Poder Público no Vetor Norte da Regiäo Metropolitana de Belo Horizonte, a partir de 2005, e a apropriação do espaço pelo mercado fundiário/imobiliário na região norte e periférica da capital, buscando-se identificar os elementos que contribuem para a alteração da ordem fundiária e, também, para a elitização dos espaços. O plano estratégico metropolitano objetiva a diversificação da base industrial da região, mediante a atração de investimentos e da criaçâo de polos de alta tecnologia. E, como forma de garantir sua maior competitividade no cenário global, é acompanhado de grandes obras públicas de infraestrutura e de suporte a serviços. A pesquisa demonstrou que as açôes modificadoras procedidas pelo Poder Público têm influenciado a valorização da terra urbana, a apropriação do espaço pelo mercado fundiário/imobiliário e a elitização da regiáo norte e periférica da capital, corroborando a tese da cidade como growth machine.

P A L A V R A S - C H A V E : cidade; regiāo metropolitana; planejamento estratégico; reestruturação econômico-espacial; desenvolvimento.

Contribution of each author: A. theoretical and conceptual basis and problematization; B. research data and statistical analysis; C. producing figures and tables; D. photographs; E. preparation and drafting of manuscript; F. selection of references.

DOI: https://doi.org/10.22296/2317-1529.2017v19n2p310 


\section{INTRODUCTION}

In current capitalist cities, the supremacy of financial capital over industrial capital has redefined the sense of space, which has also adopted the condition of a real estate product. Urbanization has become a profitable business, enabling financial capital to appropriate commodity space as the locus for productive investment, with real estate capital as a player within the space, as an individually consumable commodity in the form of private property. The spatial arrangement of the city is therefore molded by the interest of capital, which uses urban land for the purpose of increasing productive forces.

The state plays a determining role in this process as an agent that induces the (re) production of the city, both as a regulator of urban land, and as a landowner and real estate developer, directly influencing the transformation of urban space. In general, the various spatial intervention policies and projects, whether public or private, often favor the (re)possession of areas by corporate and speculative capital, promoting a strong process of land valorization and the expulsion/segregation of large numbers of poor people from different levels and regions in the cities.

Since 2005, public authorities, in conjunction with private capital, have implemented actions aimed at the economic and spatial restructuring of the North Sector of the Metropolitan Region of Belo Horizonte (MRBH), by implementing a new model of strategic management for the metropolitan space, the foundations of which have been widely discussed by authors such as Castells and Borja (1996) and Harvey (2005). These actions were contemplated in the Integrated Development Master Plan for the Metropolitan Region of Belo Horizonte (known as PDDIMRBH) (MINAS GERAIS, 2011a) and were aimed at enhancing development in the metropolitan municipalities, consolidating the role of the city of Belo Horizonte within the national economic scenario, as well as guaranteeing its greater competitiveness in the global market.

The PDDI is part of a broader political-institutional context of the process for implementing and consolidating the new metropolitan planning and management system $^{2}$. It is responsible for coordinating and integrating the various proposals, projects and programs already in existence within the scope of the state government, such as the Integrated Development Plan for Minas Gerais ${ }^{3}$ (PMDI) (MINAS GERAIS, 2007; 2016), the Development and Management Program for the Metropolitan Region of Belo Horizonte - the Plan for Immediate Actions Plan in the North Sector ${ }^{4}$ (MINAS GERAIS, 2008) and the Macro-Structural Plan for the Northern Sector of the Metropolitan Region of Belo Horizonte 5 (MINAS GERAIS, 2010).

The modification actions undertaken by the public authorities have influenced the valorization of urban land and the appropriation of space by the land and real estate markets, corroborating the thesis of the city as an urban growth machine (LOGAN; MOLOTCH, 1987).

In this perspective, the present work aims to evaluate the process of spatial and economic restructuring implemented by the public authorities in the Northern Sector of the MRBH, as of 2005, and the appropriation of space by the land and real estate markets in the north and peripheral region of the capital, seeking to identify the elements that have contributed to altering the land order and also to the elitization of spaces.
1 This article stems from the doctoral thesis of the first author, entitled (Re)estruturação urbana e o processo de gentrificação em Venda Nova - Belo Horizonte/MG (The urban (re) structuring and gentrification process in Venda Nova - Belo Horizonte/MG), from November 2015, together with the Postgraduate Studies Program in Social Sciences at the Pontifícia Universidade Católica de São Paulo (PUC$S P)$, under the guidance of Dr. Maura Pardini Bicudo Véras. The authors are grateful for the support given by the Centro Federal de Educação Tecnológica de Minas Gerais (CEFET-MG) and the Pontificia Universidade Católica de São Paulo (PUC-SP).

2 In 2006, approval of Complementary Laws 88 89 and 90 established the institutional arrangement for metropolitan management, defining the management and planning bodies of the MRBH, as well as the management tools - one of which was the PDDI-MRBH and one financial - the Metropolitan Development Fund.

3 The PMDI establishes the government's strategies for the integrated socioeconomic development of the state. Launched in 2000, the PMDI underwent a series of reviews aimed at consolidating the progress already achieved and ensuring greater effectiveness of the government actions envisaged for the period 2016 2027.

4 This foresees the actions and projects already implemented or under execution in the Northern Sector of the $\mathrm{MRBH}$, aiming to promote the expansion of local and regional accessibility, the development of ventures for technological innovation, the preservation of environmental, cultural and scientific assets and the shared management between the actors involved. 
5 Elaborated by the JURONG Consultants for the State Secretariat for Economic Development (SEDE), the Structural Plan aims to provide a general strategic orientation for the medium and long term sustainable economic development of the MRBH, establishing guidelines for land use and occupation.
In order to identify the elements that characterize the (re)structuring process of the Northern Sector of the MRBH, and to investigate the urban income from the land, the production and consumption of the urban space, the management tools and urban politics, a bibliographical study was undertaken, produced from printed or electronic materials, by national and international authors. In turn, identifying the changes, which have taken place in the urban infrastructure of the Metropolitan Northern Sector was based on official documents from the Minas Gerais State Government and the Belo Horizonte City Hall. The article is structured into five sections, in addition to this introduction. In the first section, we examine a number of theoretical perspectives on the understanding of urban space, which assist in constructing and analyzing the complexities inherent to the object of study proposed herein. In the second, we debate issues related to the reproduction of urban space and mechanisms for promoting and appropriating (urban) land income in today's capitalist cities. In the third, we debate aspects related to the socio-spatial configuration of the city of Belo Horizonte and its interdependent relationship with the adjacent municipalities. In the fourth, we highlight the strategic plans and actions adopted for the economicspatial restructuring of the Northern Sector of the Metropolitan Region, together with its implications. Lastly, we present the final considerations of the work.

\section{THE CAPITALIST (RE)PRODUCTION OF THE CITY SPACE}

Within the context of cities, the dense concentration of people and the use of land for many diverse purposes are an encouragement for land use disputes. For some, "place" constitutes a place of residence or production; for others, "place" represents merchandise to buy, sell or rent to another person (LOGAN; MOLOTCH, 1987). Produced space, under the bias of industrialization, becomes merchandise, much like most other products created by capitalist production, enabling the private ownership of urban land in aggregate social wealth.

Attracted by the advantages of agglomeration and by socializing the general conditions of production, capital appropriates urban space as a condition and means for the concrete realization of the productive cycle, during its moments of production, distribution, circulation, exchange, consumption of merchandise and, hence, profit making (TOPALOV, 1979). Cities are therefore seen as growth machines, organized as companies dedicated to increasing income levels, through the intensification of land use (LOGAN; MOLOTCH, 1987).

Thus, the valorization of land is intrinsically related to the advantages and opportunities that the location of the property may provide to the buyer/user, such as: infrastructure (electricity, public transport, water and other urban services); easy access to trade, distribution of goods; among others. Therefore, access to the privileged regions with infrastructure and service provision is restricted to the higher income groups, because of the excessive valorization (elitization) of the land, thereby relegating the poorest population to the worst served areas (SINGER, 1979).

Thus, socio-spatial transformations resulting from the distribution of productive activities and of the population in the urban space would be the result from the state and different entrepreneurial capitals as well as from strategies related to the location 
and distribution of the workforce (variants of social classes within the population), according to the conjuncture and the specificities of each place (LIMONAD, 2011).

During the final decades of the twentieth century, the deep recession of 1973, aggravated by the oil crisis, triggered substantial changes in Fordist capitalism, and initiated an uneasy period of economic restructuring and social and political readjustment. The changes represented the first signs of transition towards a new regime of accumulation - termed "flexible accumulation" (HARVEY, 2011). As a consequence, a new space was constituted on the world scale (neoliberalism), which relied on financial, information and circulation networks (LEFEBVRE, 2000). This was the capitalist city in the current monopolistic period, of so-called flexible accumulation, while being a direct product from the social relations of production, productive restructuring, technological and informational advance, globalization, planetary flows of people, information, merchandise and money (SANTOS, 1985; HARVEY, 2011; BORJA; CASTELLS, 1997; VÉRAS, 2010).

The urban fabric is then molded so as to allow the global economy to function together with the circulation on different scales, of objects (money, machinery, raw materials, merchandise, consumer goods) and subjects (in the quality of workers, and also as migrants, tourists, travelers, consumers) while being representatives of the physical-material dimension (RODRIGUES, 2010).

In this context, the speed of information regarding international markets and the resilience of cities in dealing with this, combined with the flexibility of the productive and commercial structures and the capacity to be inserted into networks, are determinants for the attractiveness of the city and its success (or failure) within the global economy, "much more than positions acquired in the past, accumulated capital, natural wealth or geographical location” (CASTELLS; BORJA, 1996, p. 153, author's translation).

Castells and Hall (1994), inspired by the North American example of Silicon Valley, argue that the structure of such cities is influenced by the simultaneous action of three interrelated processes: (i) the technological revolution based on information technology (including genetic engineering); (ii) the formation of a global economy - encompassing capital, management, labor, technology, information and markets the productivity and competitiveness of which is derived from the generation of new knowledge and access to the adequate processing of information; (iii) the emergence of information production and management, characterized by the generation of new knowledge and access to the adequate processing of information.

Castells and Hall (1994) emphasize, however, that the success of such centers in the global economy depends on the support of local, regional and national authorities; the presence of institutions dedicated to research and information; the granting of fiscal and financial incentives; the availability of industrial land; the availability of skilled labor (quality professionals and technicians); the existence of appropriate transport (motorways, port, international airport, etc.) and communication systems; the image and urban quality of the location (entertainment, leisure, culture, consumption and sociability activities); and bureaucratic flexibility. All these factors are important attractions for investors and, therefore, for the success of the technological park (to be) implanted in the city (CASTELLS; BORJA, 1996; BORJA; CASTELLS, 1997; SAVAGE; WARDE; WARD, 2003).

In the new world-wide economy, therefore, competition is intensified between 
cities, centers and peripheries, for resources and activities that include foreign investments, matrices and international institutions or tourism, among others, as a way of guaranteeing access to markets, which are increasingly more global (SASSEN, 1998).

Based on this perspective, the state plays a determining (if not principal) role as an agent that induces the (re)production of the city, both as a regulator of urban land (changing zoning and division laws, land use and occupation, installing public equipment and urban infrastructure, directing the allocation of budget investments, acting directly in the execution of urban operations, etc.), as well as being a landowner and real estate developer, directly influencing the transformation of urban space (offering services, urban infrastructure, equipment for collective consumption).

In view of this, whenever private capital implements locational advantages through real estate ventures such as shopping malls and similar, or when local governments provide a determined region with infrastructure and public services, demands are therefore attracted to this area by companies and residents, who were previously absent exactly because these particular urban services and equipment did not exist, and thus preferred to remain in other areas of the city. Clearly, these are prepared to pay higher prices for land use, either through purchase or rental, than those paid by the demands aimed at the same region when it had not yet been provided with the implanted benefits of infrastructure or public services. This is why valorization of real estate occurs in this area in relation to the others and, probably accounts for the consequent elitization.

With the changing patterns of land use, new development paths are opening up for the absorption of capital surplus, in which waves of technological and organizational innovation promote drastic transformations in the geographic landscape, implying episodes of creative destruction, in which one set of dominant forms (devalued) is succeeded by another (valued), originating new geographies (HARVEY, 2005; 2011).

\section{THE STRATEGIC RESTRUCTURING AND VALORIZATION OF URBAN SPACE}

In the current stage of capitalism, the (re)production of urban spaces is fundamentally directed towards attracting financial investments, whether through the construction of commercial, business or technology centers, or through the implementation of enterprises linked to tourism and leisure (such as convention halls, sports arenas, shopping malls, cultural centers), all from the perspective of globalizing cities.

According to Gottdiener and Feagin (1989), cities have been implementing ambitious restructuring schemes, subsidized by public resources and through state intervention. With ambitious strategic projects, public authorities have acted to render their productive and commercial structures more flexible, attract investments, promote tourism and organize major events, etc., permitting them to be inserted into the networks of the global economy, and enabling national and international competitiveness (CASTELLS; BORJA, 1996). It would seem that cities frantically sell themselves by affirming their competitiveness and locational advantages (WARD, 2004). 
According to Harvey (1989), these aspects constitute the so-called "urban entrepreneurship", in which cities, in the condition of merchandise, have been adapted to the world economic order. Strategic management plans emerge as important tools for current urban planning, designed to foster the economic growth and development of cities. Adopting practices of city marketing seeks to promote a city image that propitiates the projection of its main "products" abroad (such as tourism, culture, quality of life, advanced services, among others), increasing its "sale" on the competitive market (attracting investments and tourists, creating jobs, etc.) (BORJA; CASTELLS, 1997; KAVARATZIS, 2009).

In this new dynamic, urban marketing policies are oriented towards creating or meeting the needs of the consuming public - companies, tourists and the residents themselves (KOTLER; HAIDER; REIN, 1993). The strategic plans propose longterm integrated policies for implementing large projects that reconcile measures for economic growth and urban development with risk-based decision taking, the formulation of follow-up indicators and the involvement of public and private agents throughout the process (SÁNCHEZ, 1999; NOVAIS et al., 2007).

According to Harvey $(1989 ; 2005)$, there is a general consensus throughout the advanced capitalist world that positive benefits are obtained by cities that adopt entrepreneurial behavior in relation to economic development. Harvey considers that urban entrepreneurship may be understood as the standard conduct in urban governance that combines local government, various organizational forms of civil society and private interests, forming alliances that promote or manage urban/regional development.

Urban development strategies vary from city to city, based on reality, specific resources (natural, human, locational), the objective and on the audience to be reached. Harvey $(1989 ; 2005)$ states that there are four strategies related to urban entrepreneurship, which are not however mutually exclusive. The first focuses on: promoting specific advantages for the production of goods and services, through the exploitation of natural resources or a strategic location; the creation, through "public-private partnership" (PPP), of physical infrastructures (such as transport, communications, airport facilities) and social infrastructures (such as education, science and technology, culture) that strengthen the region's economic base; stimulating the creation of new products and technologies; reducing local costs (by granting subsidies, tax exemptions, cheap credit); the quality, quantity and costs of the local supply of labor.

The second strategy concerns the spatial division of consumption, in which the urban region seeks to improve its competitive position, focusing on the quality of life, tourism, culture and leisure as a way to attract more consumers (tourists). The third option includes control and command activities related to high finance, government, the production of knowledge, and collecting and processing information. Finally, the fourth strategy relates to the redistribution mechanisms of surplus used by central governments, as a form of urban survival, within a scenario of reduced spatial barriers and increased interurban competition.

However, Harvey (2005) emphasizes that, due to the speculative nature of strategic investments, the success of actions aimed at "selling" a city as a place that is propitious to a particular activity, firstly depends on creating an attractive urban image. Following the same logic of entrepreneurial marketing, constructing a "brand" 
for the city consists of being able to diagnose the economic and social potential of the location, in response to the demands of the companies and target sectors, followed by an assessment of the positive and negative aspects that should be highlighted or modified when disseminating the image of the city (COMPANS, 1999).

The orchestrated production of a dynamic, entrepreneurial, socially-integrated image of a city is apt to receive external capital and stimulate the circulation of capital and the 'right' people, if successful, attract economic investments and other forms of progress (KOTLER; HAIDER; REIN, 1993; COMPANS, 1999; HARVEY, 2005).

However, according to this perspective, it should be recognized that the contemporary version of urban entrepreneurship may mask the possible contrasts between the apparent strength of regeneration projects in urban economies and the underlying social and economic problems, especially in Brazilian cities. This paradox in many cities tends towards a dual geographic character, exteriorized by regenerating a run-down area and a surrounding sea of increasing poverty (HARVEY, 2005), in which public policies show little sensitivity to the basic needs of citizens (providing housing, health, education, employment, better working conditions, spaces for social coexistence, etc.).

The dissemination of local development strategies, to ensure a greater attractiveness of cities, implies the ennoblement of regions that undergo urban and environmental interventions (HARVEY, 2005). With the objective of producing a homogeneous urban space that is attractive to international capital, urban interventions often end up promoting merciless social cleansing - through real estate expropriation, forced resettlement and expulsion of the native population.

\section{BELO HORIZONTE AND THE EXPANSION OF THE METROPOLITAN NORTH SECTOR}

Inaugurated on December $12^{\text {th }}, 1897$, the city of Belo Horizonte was conceived as Brazil's first entirely planned city, with the purpose of becoming the state capital of Minas Gerais. From the outset, the development of the city was marked by only observing the guidelines drawn up in its basic plan only for the area defined as urban - in which the infrastructure, services and commerce were concentrated. Outside the urban area, growth occurred in a more spontaneous, disorganized manner, especially from the 1940s and 1950s, when the expansion of Belo Horizonte became propelled by the industrialization process and by the increased occupation of the peripheral areas, with a growing relationship of interdependence (economic and social) between the capital and the surrounding municipalities (ANDRADE, 2009; COSTA, 2009).

As from 1956, six expansion axes were identified in Belo Horizonte: South, Southwest, West, East, North-Central and North, presenting a polarized "north $x$ south" configuration, due to the concentration of the wealthiest layers of the population in the southern region and, on the opposite extreme, to the low-income occupation of areas with limited infrastructure and services (ANDRADE, 2009; COSTA; MENDONÇA, 2010). The sprawling growth of the city later unleashed the metropolization process of the region and led, in mid-1973, to the creation of the MRBH. 
Currently, the city of Belo Horizonte covers an area of $331.0 \mathrm{~km}^{2}$, which is subdivided into nine Administrative Regions: Barreiro; Central South; East; West; Northeast; Northwest; North; Pampulha; and Venda Nova, with the purpose of facilitating the planning and management of the city.

Occupation of the Northern Axis of the municipality was characterized by little development and by the low-income population in popular settlements, mainly in the North and Venda Nova Regions. Similarly, during the metropolization process, the poorest segments of the population were more concentrated in some of the municipalities located in the so-called Northern Sector of the MRBH, namely: Confins, Lagoa Santa, Matozinhos, Pedro Leopoldo, Ribeirão das Neves, Santa Luzia, São José da Lapa and Vespasiano (MINAS GERAIS, 2006; PREFEITURA MUNICIPAL DE BELO HORIZONTE, 2008; SOUZA; BRITO, 2008; ANDRADE, 2009; COSTA, 2009; DINIZ; MONTE-MÓR, 2012).

Thus, the structuring of the Northern Sector of the MRBH consisted of contrasting regions with settlements facing the wealthier sections of the population, and others geared towards the lower income strata, in which the planned and the unplanned, the legal and illegal, alternated within the conformation of the space (CARDOSO, 2003; KAMEL, 2007; ANDRADE, 2009).

\section{THE NORTHERN SECTOR OF THE MRBH AND THE RESTRUCTURING STRATEGY FOR THE METROPOLITAN SPACE}

During the first decade of the $21^{\text {st }}$ century, in contrast to the reduction in public and private investments of the previous decades, there was a series of structural interventions in the space of the MRBH. With the establishment of a new form of institutional metropolitan management, an attempt was made to leverage the continuation of economic growth and of the productive reorganization of the region. Studies developed in order to elaborate the MRBH Integrated Development Master Plan (known as the PDDI) made it possible to identify the metropolitan's problems and propose policies and programs for the state government to implement, with the collaboration and integration of municipalities and civil society. The mid-term time reference adopted for this was the year 2023, and the long-term was 2050 . The strategic schedule of the state aimed to build an economic environment that is competitive, stable, investor-friendly and attractive to the development of business (MINAS GERAIS, 2007), for which the main guideline was the construction of a participatory, integrated and perennial planning process (COSTA, 2009; DINIZ; MONTE-MÓR, 2012).

In turn, the "Strategic Plan for Belo Horizonte 2030 - the city we would like" (known as the PEBH), from 2009, is aligned with the strategic plans, programs and projects for the socioeconomic development elaborated by the state for the metropolitan context. According to the PEBH, the reconfiguration of Belo Horizonte, with the development of new hubs of economic dynamism, involves attracting technologybased industries; the production of goods and provision of high value-added services; and the development of services associated with tourist centers (PREFEITURA MUNICIPAL DE BELO HORIZONTE, 2009). 
The economic development plans adopted by the public authorities of the state and municipality of Belo Horizonte begin with the same premises, and demonstrate the practices of urban entrepreneurship in conducting the new processes of strategic regional planning and management. "Planning", herein, involves the creation of an "image"; long-term horizons under conditions of uncertainty; opportunities and threats; strengths and weaknesses; strategies for different scenarios ("better future" or "overcoming adversity"); goals and results; PPPs; urban governance; stakeholders; insertion as a metropolis/global city; a transition from the production mode towards segments that privilege the generation of products or services strong in knowledge and innovation; decreased costs and increased profits (MINAS GERAIS, 2007; PREFEITURA MUNICIPAL DE BELO HORIZONTE, 2009).

Among the restructuring actions implemented in the MRBH, we are particularly interested in the series of programs and projects aimed at attracting private interest/ investment and stimulating the development of the Northern Sector of the MRBH. The productive restructuring of the Northern Sector of the MRBH aims to diversify its industrial base and create high technology hubs, attracting leading national and international industries in aeronautics, biotechnology, semiconductors, information, microelectronics, software, pharmacochemistry, etc., which will use the infrastructure provided by the Tancredo Neves International Airport (IATN) for the airway transportation of products. The production of higher value-added goods in stateof-the-art sectors aims to intensify their regional polarization capacity, also favoring their competitive internationalization on the global market (MINAS GERAIS, 2007; 2010; COSTA; MAGALHĀES, 2011).

Development of the high technology sector in the region is linked to a set of factors that condition the success of the strategic plan, such as: urban infrastructure (transportation, communication, energy), specialized services, the presence of research institutions, the concession of fiscal and financial incentives, urban and environmental quality of life, and entertainment, leisure, culture and consumption activities (COSTA, MAGALHÂES, 2011). In other words, these would be the fundamental requirements for attracting investment and a highly-skilled workforce. It should be noted that investment decisions are not only associated with institutional factors and the competitiveness of the economy, but are also influenced by providing an environment conducive to social coexistence and with quality of life.

Throughout this process, public authorities have acted as promoters and coordinators of urban expansion, taking on the implantation of works that induce the creation of new enterprises and the development of localization and agglomeration economies. The strategic plan for developing the Northern Sector of the MRBH is

6 Understood as those that "unleash ruptures on the physical and social spaces in multiple dimensions and contribute to the consolidation of changes in socio-spatial dynamics, characterized by scalar reconfigurations and the effects of unequal development on a local scale." (NOVAIS et al., 2007, p. 6, author's translation)." anchored in the structuring capacity of four "large-scale urban projects": (i) AITN - An international hub for passenger and cargo transportation, and the country's first industry airport, located in Confins. Characterizing the AITN as an industry airport provides high-tech companies who wish to move into the region, with the possibility of federal and state tax exemption, both for importing components and for exporting high-value added final products, which renders them more competitive in the global market; (ii) the "Green Line" - an expansion and modernization project for the MG-10 highway, which connects the center of the capital directly to the AITN; (iii) the Administrative Center (CAMG) - located along the edge of the "Green Line", currently houses the direct administration bodies and part of the 
indirect administration of the state government. The installation of the CAMG in an area marked by marginalized occupation symbolically alters the central locus of the state's political power, promoting the development of the region; and (iv) the North Road Ring (Rodoanel Norte) - which together with the "Green Line", forms the main structure upon which the design of the entire metropolitan transportation network is based. The North Road Ring will link the AITN to the main industrial areas of the MRBH, thus supporting activities of the logistics platform for industrial development, as well as improving access from Belo Horizonte to the cities of Sáo Paulo, Brasília, Vitória and Rio de Janeiro (MINAS GERAIS, 2006; 2008; 2010; 2011a; PREFEITURA MUNICIPAL DE BELO HORIZONTE, 2008; COSTA, 2009; COSTA; MAGALHÂES, 2011; DINIZ; MONTE-MÓR, 2012).

By favoring the (re)production of metropolitan space, these four megaprojects contribute to the creation of positive externalities and new fronts for the valorization of capital, such as the implementation of BH-TEC - a technology park in Belo Horizonte, focused on Research and Development ( $\&$ \& ), for the production of innovative and high technology goods and services, the installation of the Technological Industrial Hub in Vespasiano (first South American nanotechnology), the Industrial Hub of Microelectronics and the Aerospace Technology and Training Center in Lagoa Santa, which were all aimed at manufacturing high value-added products. In addition to stimulating large amounts of public / private resources, these projects have also boosted urban development in the region, modifying patterns of social and economic use and occupation in surrounding areas, reversing the process of occupation by the low-income population that marked the periphery (MINAS GERAIS, 2006; PREFEITURA MUNICIPAL DE BELO HORIZONTE, 2008; COSTA; MENDONÇA, 2010).

In the wake of the AITN, CAMG, the "Green Line" and the North Ring Road, the land in the Northern Sector of the MRBH has been significantly valorized, thereby stimulating the performance of the economic agents who see in the new territorial arrangement a manner with which to increase the investment possibilities of capital (including speculation) and extract additional income (PREFEITURA MUNICIPAL DE BELO HORIZONTE, 2008; SOUZA; BRITO, 2008; COSTA, 2009; COSTA; MENDONÇA, 2010, 2012; DINIZ, 2015).

The PDDI-MRBH (MINAS GERAIS, 2011b, p. 50) indicates intense activity in the region on the real estate market, the verticalization of areas best served by infrastructure and closer to the CAMG, "the implementation of which has been greatly appreciated in the surrounding districts" (author's translation), speculation in relation to the price of real estate and a rise in the number of residential condominiums, with structures destined for consumption and leisure, aimed at the more affluent classes. Among the new "fortified enclaves" (SALGUEIRO, 1998; CALDEIRA, 2000), either already built or in the implantation phase in the Northern Sector of the MRBH, are: (i) "Alphaville Minas Gerais"; (ii) "Precon Park"; (iii) the "Royal Reserve - Resort Condominium"; and (iv) the "Porto do Rio Golf Village Resort"10 (MINAS GERAIS, 2008, 2014, COSTA, MENDONÇA, 2012; DINIZ, 2015), the consequences of which, in terms of pressure for accessibility, new patterns of consumption and housing, demand further studies so as to determine their development and specificities.

Linked to this, there has been a substantial growth of condominiums of varying sizes, with areas for collective use, built by national/regional developers/builders
7 A residential condominium located in Vespasiano, along the edge of the "Green Line" and close to CAMG. The enterprise has 542 residential lots (all sold at launch), with areas of 450 to 790 square meters, complete infrastructure and will contain commercial areas and a club of $14.751 \mathrm{~m}^{2}$, with structures for the residents to enjoy rest, recreation and sports.

8 An enterprise located between the municipalities of Pedro Leopoldo, Lagoa Santa and Confins, with an approximate area of 11 million $\mathrm{m}^{2}$ Designed to be a technohub, the project encompasses: (i) companies; (ii) R \& D centers; (iii) single and multifamily residential condominiums (standard and luxury); (Iv) educational institutions; (V) trade centers, including a shopping mall; (Vi) convention center; (Vii) hotels; (Viii) entertainment, sports areas (including a multi-use stadium for 35 thousand spectators), leisure (with an amusement theme park) and health. The works started in the first half of 2015

9 A development located in the municipality of Jaboticatubas, in an area of more than 10 million $\mathrm{m}^{2}$. Termed "the first Prime Community of Brazil," it will consist of commercial, leisure, service centers and four residential condominiums: (i) Fly-in Community, with 192 residences, a 1,600meter landing strip, private hangars and a heliport; (ii) Golf Resort, with 517 lots of $1,000 \mathrm{~m}^{2}$, a golf course and complete infrastructure for sports, in addition to a boutique hotel; (iii) Biovillas, with avenues of classic and contemporary houses; and the (iv) Equestrian Resort, with 165 residences.

10 High-end development situated between the municipalities of Jaboticatubas and Lagoa Santa, will consist of a hotel, a large resort, aimed at elite sports, with golf course, spa, equestrian center and convention center, and a residential development. 
(MRV, Tenda, Rossi, Direcional) that specialize in the middle income brackets and which, until that time, had little or no participation in the municipalities that make up the Northern Sector of the capital (MINAS GERAIS, 2014; DINIZ, 2015)

The expansion of these types of enterprises indicates a change in land use and occupation in the region, and are attracting sections of the population with a greater purchasing power to these suburban condominiums strategically located in the municipalities that make up the area influenced by the structuring megaprojects, such as Jaboticatubas, Lagoa Santa, Vespasiano, Pedro Leopoldo, Confins, Matozinhos e Santa Luzia. The migration of those with a higher income to areas previously occupied by the low income population adds a new element to the traditional horizontal expansion of poverty: "the peripherization of wealth", generating new movements to expel the poorest and, consequently, the gentrification of spaces (PREFEITURA MUNICIPAL DE BELO HORIZONTE, 2008; SOUZA; BRITO, 2008; COSTA, 2009; COSTA; MENDONÇA, 2010, 2012; MINAS GERAIS, 2014; DINIZ, 2015).

Attracted by the development scenario and by the population's improved income levels and purchasing power, large department stores, of national/regional scope and a strong potential for attracting consumers, began to operate within the region. There has also been a transformation in the built-up environment and the urban landscape of the Northern Vector of the MRBH, through increased urban infrastructure, in cultural, leisure, sports and transport equipment; the installation of a multimodal transport station ("Vilarinho Station") together with the first large mall in the region; the provision of new private higher education institutions, new public and private health centers, and other commercial activities that previously had either been nonexistent or limited within the region. Hence, the locational advantages implemented in the Northern Sector of the MRBH have made it more attractive and, consequently, more valorized (DINIZ, 2015).

The installation of these large-scale projects has impacted the land market in the Northern Sector of the MRBH, with a significant increase in real estate transmission tax (ITBI) between 2000 and 2010. This fact reflects not only the increase in the volume of real estate business (buying/selling) but also the growth of this market within the region, with a significant demand for houses, apartments and plots of land for both residential and commercial purposes (SATHLER et al., 2011).

A significant increase in the value of land in the North Sector of the MRBH is highlighted by the real estate market analysis in the Venda Nova Administrative Region in Belo Horizonte. Based on a survey of the real estate classified sections of the newspaper Jornal Estado de Minas, one of the most important printed newspapers in the state, the amount of residential property put up for sale/lease was measured in the months of January and July in the period between 2001 and 2013, including properties with different characteristics. The use of real estate advertisements as a source of information in the real estate market is used in countries such as Austria, Spain, US, Hungary and the UK, and is also adopted by the Foundation for Economic Research (FIPE), in order to produce a national price index of real estate.

According to data obtained through our research, the average value of residential properties for sale in January 2001 was $\mathrm{R} \$ 40,765.43$, and by July 2013, the average value of the properties had changed to $\mathrm{R} \$ 290,205.17$, representing a significant increase of $712 \%$ in property prices. Following the development of sales prices, the 
average rental value of residential properties for lease in January 2001 was $R \$ 221.36$, and by July 2013 , the average rent had risen to $R \$ 813.50$, representing an increase of $368 \%$ in the value of the lease. During this period, the accumulated inflation as indicated by the General Market Price Index (IGP-M) was 175\%, while the accumulated increase of the minimum salary in the country was $277 \%$. These indices, therefore, are lower than the percentage increase in the price of real estate offered in the Venda Nova administrative region. It should be noted that the gradual increase in real estate value coincides with the presence of the new public and private enterprises in the Northern Sector of the MRBH (DINIZ, 2015).

Thus, as a result of the investments made/programmed for the Northern Sector of the $\mathrm{MRBH}$, the territorial dynamics of the region are marked by strong pressure on the real estate market (speculation, rising land price, etc.), with repercussions on the permanence (or otherwise) of the low-income populations in the region. Expanding the actual demand for real estate and, consequently, the intense valorization of real estate over recent years, indicates the contrast of expelling the most vulnerable sections of the population to more distant peripheries (PREFEITURA MUNICIPAL DE BELO HORIZONTE, 2012; MINAS GERAIS, 2014; DINIZ, 2015).

\section{FINAL CONSIDERATIONS}

In times when everything tends towards merchandization and exchange-value overrides use-value, the hierarchical appropriation of space occurs for and because of money - favored, incidentally, by the role of the state as planner and regulator with consequences in the social configuration and (unequal) development of urban space. As "growth machines" (LOGAN; MOLOTCH, 1987), cities - their spaces and their respective conditions of production (LOJKINE, 1997) - are organized so as to intensify land use and, as a consequence increase levels of income.

Faced with the economic reorganization brought about by the flexibilization and spatial deconcentration of production, the capitalist cities of the current monopolistic period adjust their spatial configuration to the new needs of the economy. This movement of urban restructuring and the provision of localized advantages (attractive physical space, infrastructure, transport network and services) aim to insert cities and/ or make them more competitive within the global urban network (HARVEY, 1989; CASTELLS; BORJA, 1996; WARD, 2004; FERREIRA, 2005).

Consolidating the "conceived space" (LEFEBVRE, 2000) of the Northern Sector of the MRBH is aimed at guaranteeing the increased reproduction of capital, by providing new urban enterprises/services (installed or undergoing installation) through investments, public and private, and which are structured from large equipment, such as: CAMG; The "Green Line"; expanding the functions at AITN; and implementing the North Ring Road, among others.

It should be emphasized that the valorization of real estate perceived in the region has not arisen exclusively from the presence of new developments. It has also been influenced by conjunctural factors linked to the very dynamic of the market, the growth of the gross domestic product (GDP) and the average family income, the intensified demand for land by economic activities, the availability of credit and the 
Luciano dos Santos Diniz holds a law degree from the Universidade FUMEC; a Master's degree in law from Pontifícia Universidade Católica de Minas Gerais (PUC-Minas); and a $\mathrm{PhD}$ in Social Sciences from the Pontifícia Universidade Católica de São Paulo (PUC-SP); he is an associate professor in the Department of Applied Social Sciences at the Centro Federal de Educação Tecnológica de Minas Gerais (CEFET-MG).

E-mail: lucianodiniz@dcsa. cefetmg.br

Maura Pardini Bicudo Véras holds a graduate, Master degree and Doctorate from the Pontifícia Universidade Católica de São Paulo (PUC-SP) where she is also a Professor of Social Sciences; she is a Postdoctoral fellow of the Institut d'Études Politiques, Paris-France; a productivity researcher with CNPq; a full professor at the Sociology Department of PUC-SP and a coordinator at the Núcleo de Estudos e Pesquisas Urbanos (NEPUR) of PUC-SP.

E-mail:mmveras@pucsp.br

Article received on 8th May 2016 and approved for publishing on 2nd December 2016 . falling returns of the financial market that led capital from various sources to seek the real estate market for its reproduction. As if this were not sufficient, as of 2004, there was also a favorable political environment for propelling the real estate market, due to the housing policies implemented across the country, such as the My Home, My Life Program, for example. (SATHLER et al., 2011).

Nevertheless, the interventions carried out by public authorities redesigned the spatial structures of the Northern Sector of the MRBH, opening new fronts of investment and accumulation, with the significant valorization of land. Improvements in urban infrastructure were accompanied by changes in commercial facilities and by the provision of public and private services, attracting residents with higher income levels to the region. On the other hand, the increased "ground rent" and cost of goods and services threatened the permanence of the former low-income inhabitants, thereby explaining the elitization of the spaces.

The restructuring process, however, is in its early stages, making it evident that further studies are clearly needed, along with a concerted effort to determine its development and specificities, especially considering the medium- and long-term perspectives of the strategic socioeconomic development foreseen for the Northern Sector of the MRBH.

\section{REFERENCES}

ANDRADE, L. T. (Org.). Como anda Belo Horizonte. Rio de Janeiro: Letra Capital: Observatório das Metrópoles, 2009.

BORJA, J., CASTELLS, M. Local y global: la gestión de las ciudades en la era de la información, Madrid: Taurus, 1997.

CALDEIRA, T. P. R. Cidade de Muros: Crime, Segregação e Cidadania em São Paulo. São Paulo: Editora 34, Edusp, 2000.

CARDOSO, A. L. Irregularidade urbanística: questionando algumas hipóteses. Cadernos Metrópole, n. 10, p. 9-25, jul./dez. 2003. Available at: <http://revistas.pucsp.br/index. php/metropole/article/view/9197>. Accessed on: 15th Dec. 2016.

CASTELLS, M., BORJA, J. As cidades como atores políticos. Novos Estudos CEBRAP, n. 45, p. 152-166, jul. 1996. Available at: <http://novosestudos.uol.com.br/v1/files/uploads/ contents/79/20080626_as_cidades_como_atores.pdf >. Accessed on: 15th Dec. 2016.

CASTELLS, M.; HALL, P. Tecnópolis del mundo: la formación de los complejos industriales del siglo XXI. Madrid: Alianza, 1994.

COMPANS, R. O paradigma das global cities nas estratégias de desenvolvimento local. Revista Brasileira de Estudos Urbanos e Regionais, n. 1, p. 91-114, maio 1999. https://doi. org/10.22296/2317-1529.1999n1p91

COSTA, G. M. Produção do espaço metropolitano em Belo Horizonte, Brasil: revisitando a economia política da urbanização. In: ENCUENTRO DE GEÓGRAFOS DE AMÉRICA LATINA, 12., 2009, Montevidéu. Anales.... Montevidéu, 2009. Available at: $<$ http://observatoriogeograficoamericalatina.org.mx/egal12/Geografiasocioeconomica/ Geografiaurbana/46.pdf >. Accessed on: 15th Dec. 2016.

; MAGALHÃES, F. N. C. Processos socioespaciais nas metrópoles de países de industrialização periférica: reflexôes sobre a produção do espaço metropolitano de Belo Horizonte, Brasil. Revista Brasileira de Estudos Urbanos e Regionais, v. 13, n. 1, p. 9-25, maio 2011. https://doi.org/10.22296/2317-1529.2011v13n1p9 
COSTA, H. S. M.; MENDONÇA, J. G. Urbanização recente e disputa pelo espaço na dinâmica imobiliária metropolitana em Belo Horizonte. In: ENCONTRO NACIONAL DE ESTUDOS POPULACIONAIS, 17., 2010, Caxambu. Anais... Caxambu: ABEP, 2010.

; _-_____. Novidades e permanências na produção do espaço da metrópole: um olhar a partir de Belo Horizonte. In: OLIVEIRA, F. L. et al. (Org.). Grandes projetos metropolitanos. Rio de Janeiro e Belo Horizonte. Rio de Janeiro: Letra Capital, 2012. p. 46-65.

DINIZ, L. S. (Re)estruturação urbana e o processo de gentrificação em Venda Nova - Belo Horizonte/MG. 2015. 328 f. Thesis (Doctorate in Social Sciences) - Pontifícia Universidade Católica de São Paulo, São Paulo, Brasil, 2015. Available at: <https://sapientia.pucsp.br/ handle/handle/3693>. Aecessed on: 15th Dec. 2016.

DINIZ, S. C.; MONTE-MÓR, R. L. M. A pequena produção popular e solidária como instrumento de fortalecimento e reorganização metropolitana: a visão do PDDIMRBH. In: SEMINÁRIO SOBRE A ECONOMIA MINEIRA, 15., 2012, Diamantina. Anais... Belo Horizonte: CEDEPLAR/UFMG, 2012. Available at: <http:// web.cedeplar.ufmg.br/cedeplar/seminarios/ecn/ecn-mineira/2012/arquivos/A\%20 pequena $\% 20$ produ $\%$ C3\%A7\%C3\%A3o\%20popular\%20e\%20solid\%C3\%A1ria. pdf>. Accessed on: 15th Dec. 2016.

FERREIRA, A. F. Gestão Estratégica de Cidades e Regióes. 1. ed. Lisboa: Fundação Calouste Gulbenkian, 2005.

FUNDAÇÃO JOÃO PINHEIRO. Mapa das Regionais Administrativas de Belo Horizonte. Elaborado por Priscilla Costa Pereira. Belo Horizonte, 2015.

GOTTDIENER, M.; FEAGIN, J. R. Uma mudança de paradigma na sociologia urbana. Espaço \& Debates, ano IX, n. 28, p. 44-58, 1989.

HARVEY, D. From managerialism to entrepreneurialism: the transformation in urban governance in late capitalism. Geografiska Annaler, v. 71, n. 1, p. 3-17, 1989. https://doi. org/10.2307/490503

A produção capitalista do espaço. São Paulo: Annablume, 2005.

Condição Pós-Moderna: uma pesquisa sobre as origens da mudança cultural. 21. ed.

São Paulo: Loyola, 2011.

Os limites do capital. 1. ed. São Paulo: Boitempo Editorial, 2013.

KAMEL, R. C. A. Gestão municipal e o processo de organização do espaço urbano da cidade de Belo Horizonte (1894-1960). Belo Horizonte: Fundação João Pinheiro, 2007.

KAVARATZIS, M. What can We Learn from City Marketing Practice? European Spatial Research and Policy, v. 16, n. 1, p. 41-58, jan. 2009. https://doi.org/10.2478/v10105009-0003-7

KOTLER, P.; HAIDER, D.; REIN, I. Marketing places: attracting investment, industry and tourism to cities, states and nations. New York: The Free Press, 1993.

LEFEBVRE, H. La production de l'espace. 4. ed. Paris: Anthropos, 2000.

LIMONAD, E. Urbanização e organização do espaço na era dos fluxos. In: SANTOS, M. et al. (Org.). Território, territórios: ensaios sobre o ordenamento territorial. 3. ed. Rio de Janeiro: Lamparina, 2011. p. 145-170.

LOGAN, J. R.; MOLOTCH, H. L. Urban fortunes: the political economy of place. Berkeley-CA: University of California Press, 1987.

LOJKINE, J. O estado capitalista e a questão urbana. 2. ed. São Paulo: Martins Fontes, 1997.

MINAS GERAIS. Secretaria de Estado de Planejamento e Gestão. EIA - Estudo de Impacto Ambiental do Centro Administrativo do Estado de Minas Gerais. v. 1. Belo Horizonte: Lume Estratégia Ambiental Ltda., dez. 2006.

Secretaria de Estado de Planejamento e Gestão. PMDI 2007-2023 - Estratégia de Desenvolvimento. Belo Horizonte: Secretaria de Estado de Planejamento e Gestão, 2007. 
Secretaria de Estado de Desenvolvimento Regional e Política Urbana (SEDRU). Programa de Desenvolvimento e Gestão da Região Metropolitana de Belo Horizonte Plano de Açóes Imediatas para o Vetor Norte. Belo Horizonte: Instituto Horizontes, 2008. Secretaria de Estado de Desenvolvimento Econômico (SEDE). Plano Macro-Estrutural do Vetor Norte da Região Metropolitana de Belo Horizonte (MRBH). Belo Horizonte: JURONG Consultants Pte Ltd., 2010.

Secretaria de Estado de Desenvolvimento Regional e Política Urbana (SEDRU). Plano Diretor de Desenvolvimento Integrado da Regiāo Metropolitana de Belo Horizonte - PDDI-MRBH - Relatório de Definição das Propostas de Políticas Setoriais, Projetos e Investimentos Prioritários - Sumário Executivo. Belo Horizonte: UFMG CEDEPLAR/FACE, abr. 2011a.

. Secretaria de Estado de Desenvolvimento Regional e Política Urbana (SEDRU). Plano Diretor de Desenvolvimento Integrado da Região Metropolitana de Belo HorizontePDDI-MRBH - Propostas de Políticas Setoriais, Projetos e Investimentos Prioritários - Volume 1. Belo Horizonte: UFMG - CEDEPLAR/FACE, maio 2011b.

- Agência de Desenvolvimento da Região Metropolitana de Belo Horizonte (AMRBH). Projeto do Macrozoneamento da Regiäo Metropolitana de Belo Horizonte (MZ-MRBH). Produto 2 - Avaliação das Tendências Recentes da Dinâmica Territorial da MRBH e Identificação Preliminar das Zonas de Interesse Metropolitano. Belo Horizonte: UFMG - CEDEPLAR, maio 2014.

Secretaria de Estado de Planejamento e Gestão. PMDI 2016-2027 - Desenvolvimento Econômico e Social Sustentável de Minas Gerais - Redução das desigualdades sociais e regionais. Belo Horizonte: Secretaria de Estado de Planejamento e Gestáo, 2016.

NOVAIS, P. et al. Grandes projetos urbanos: panorama da experiência brasileira. In: ENCONTRO NACIONAL DA ANPUR, 12., 2007, Belém. Anais... Belém: ANPUR, 2007. Available at: <http://unuhospedagem.com.br/revista/rbeur/index.php/anais/ article/view/2390>. Accessed on: 15th Dec. 2016.

PREFEITURA MUNICIPAL DE BELO HORIZONTE. Estudo sobre os impactos oriundos de iniciativas localizadas no eixo norte da MRBH e definição de alternativas de desenvolvimento econômico, urbano e social para o município de Belo Horizonte. Relatório Final. Volume III. Avaliação dos Impactos Relativos aos Projetos com Influência na Dinâmica de Desenvolvimento do Município de Belo Horizonte. Belo Horizonte: PMBH, maio 2008.

. Planejamento estratégico de Belo Horizonte 2030. Belo Horizonte, PMBH, 2009.

. Plano Diretor da Região Administrativa Venda Nova - diagnóstico da área: situação atual e tendências da dinâmica urbana. vol. 1. Belo Horizonte: Práxis Projetos e Consultoria Ltda., mar. 2012.

RODRIGUES, W. Cidade em transição: nobilitação urbana, estilos de vida e reurbanização em Lisboa. Lisboa: Celta Editora, 2010.

SALGUEIRO, T. B. Cidade pós-moderna: espaço fragmentado. Revista Território, ano 3, n. 4, p. 39-53, jan./jun.1998.

SÁNCHEZ, F. Políticas urbanas em renovação: uma leitura crítica dos modelos emergentes. Revista Brasileira de Estudos Urbanos e Regionais, n. 1, p. 115-132, maio 1999. https:// doi.org/10.22296/2317-1529.1999n1p115

SANTOS, M. A caminho de uma teoria substantiva da urbanização. Revista Orientação, n. 6, p. 81-84, nov. 1985 .

SASSEN, S. As cidades na economia mundial. São Paulo: Studio Nobel, 1998.

SATHLER, D. et al. O impacto dos grandes empreendimentos no mercado da terra na MRBH: o Vetor Norte em perspectiva. Geografias, v. 7, n. 1, p. 9-28, jan./jun. 2011. Available at: <http://www.igc.ufmg.br/portaldeperiodicos/index.php/geografias/ 
article/view/534>. Accessed on: 15 th Dec. 2016.

SAVAGE, M.; WARDE, A.; WARD, K. Urban sociology, capitalism and modernity. 2. ed. Londres: Palgrave Macmillan, 2003.

SINGER, P. O uso do solo urbano na economia capitalista. In: MARICATO, E. (Org.). A produção capitalista da casa (e da cidade) no Brasil industrial. São Paulo: Alfa-Omega, 1979. p. 21-36.

SOUZA, J.; BRITO, F. Expansão urbana de Belo Horizonte e da MRBH: A mobilidade residencial e o processo de periferização nos anos 80 e 90. In: SEMINÁRIO SOBRE A ECONOMIA MINEIRA, 13., 2008, Diamantina. Anais... Belo Horizonte: CEDEPLAR/UFMG, 2008. Available at: <http://gestaocompartilhada.pbh.gov.br/ sites/gestaocompartilhada.pbh.gov.br/files/biblioteca/arquivos/a_expansao_urbana_ em_bh_1.pdf $>$. Accessed on: 15th Dec. 2016.

TOPALOV, C. La Urbanización capitalista: algunos elementos para su análisis. México: Edicol, 1979.

VÉRAS, M. P. B. Cidade, vulnerabilidade e território. Ponto e virgula, n. 7, p. 32-48, 2010. Available at: <http://revistas.pucsp.br/index.php/pontoevirgula/article/view/13959>. Accessed on: 15th Dec. 2016.

WARD, S. V. Selling places: the marketing and promotion of towns and cities 1850-2000. London: Spon Press, 2004. 